\title{
External debt-growth nexus: Empirical evidence from Ethiopian economy
}

\section{Wondatir Atinafu}

Department of Economics, Jimma University, Ethiopia

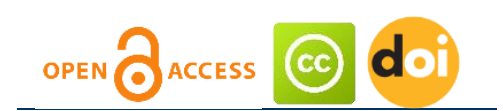

Article history:

Received: June 12, 2020

1st Revision: September 16, 2020

Accepted: October 31, 2020

JEL classification:
C22
F34
F43

DOI:

10.14254/jems.2020.5-2.1
Abstract: This study is an effort to determine the effect of public external debt on economic growth in Ethiopia. Specifically, the study tries to answer the questions whether stock of public external debt and public external debt servicing have any significance effect on economic growth of the country and it also determined the magnitude of the effect. In doing this, the study used an Auto Regressive Distributive Lag model (ARDL modeling) to analyze Ethiopian data from 1970 up to 2017 with real GDP as a function of stock of public external debt, public external debt servicing, human capital, physical capital, trade openness, labor force and policy change dummy. The empirical result reveals that in the long-run high level of stock of public external debt has a significant negative effect on economic growth and it poses great challenges on the economy. Hence, there is an evidence for the "Debt overhang" and "Conventional view" of public debt in Ethiopia. On the other hand, public external debt servicing has a negative coefficient but insignificant in affecting economic growth and there is no evidence for the "Crowding out" effect in the country. In the long-run result, human capital is also found to have negative impact on real GDP. Moreover, physical capital has a significant positive impact but labor force and trade openness is insignificant in explaining the Ethiopian economy. Hence, this study recommended the government of Ethiopia and local policy makers to improve the existing policies on public external debt management such as to invest in productive activities and sectors, to implement structural change, public sector reform and tax reform, should try to minimize the dependence on external borrowing through diversifying the economy so as to generate more revenue in the domestic.

Keywords: Ethiopia, external debt stock, external debt servicing, ARDL and economic growth. 


\section{Introduction}

External debt is an important source of finance mainly used to supplement the domestic sources of funds for supporting development and other needs of a country. Usually external debt is incurred by a country which suffers from shortages of domestic savings and foreign exchange needed to achieve its developmental and other national objectives. However, if the external debt is not used in income-generating and productive activities, the ability of a debtor nation to repay the debt is significantly reduced. It is often argued that the excessive debt constitutes an obstacle to sustainable economic growth and poverty reduction (Berensmann et al., 2004).

Countries with less developed domestic debt markets often rely on external borrowing to meet their financing needs. This is because the domestic debt market is shallow and cannot match the government financing requirements. As a result, their debt portfolio is mainly composed of external debt. Although most countries in East Africa have over time deepened their domestic markets, a large proportion of their foreign borrowing is denominated in foreign currency. While the external financing is mainly from concessional sources, the challenge of managing external debt remain prevalent. Chawdhury (2001) admits that external debt may have huge effects on the overall performance of these countries. Mukui (2013) observes that high levels of external debt in Ethiopia poses a great challenge to the economy given that a large proportion of the export income goes to servicing debts instead of being put into domestic investment.

One of the greatest problems facing many Sub-Saharan African countries today in general and Ethiopia in particular is therefore, the amount of their external indebtedness. The external debt problem is becoming more acute for a number of reasons. First, the size of the debt relative to the size of the economy is enormous and can lead not only to capital flight but also may discourage private investment. Secondly, debt servicing payments form a significant proportion of the annual export earnings. Meeting debt servicing obligations eats significantly in to whatever other services can be provided to improve the welfare of the citizens and therefore has macroeconomic implications. This raises the question of whether a country can grow fast enough to maintain debt obligations and adequate domestic investment. Thirdly, the burden of debt for a large number of SubSaharan African countries threatens not only the execution but also the prospects of success of adjustment programs being embarked up on. Fourth, the current system of debt management has a dire macroeconomic impact on an economy's output (Ajayi, 1991).

The objectives of new Ethiopia to end poverty are challenged by lack of adequate domestic financial resources for development finance among others. Economic theories have shown that financial resources are more important than natural resources in the process of economic development. A country richly endowed with natural resource cannot use them fruitfully without capital and skilled labor, the availability of which depends up on financial resources. According to Hicks (1965), choosing appropriate method of finance cannot make a bad plan good, but it can make it better, using wrong methods can wreck even the best plan. Rosenstein Rodan in his theory of big push pointed out that for achieving economic progress, investment at initial stage must be sufficiently big to bring a country into self-sustaining growth. Economists preached adequate mobilization of financial resources as basic issue to the whole questions of economic development. But this important factor of development is very scarce in Ethiopia.

The revenue productivity of taxes in Ethiopia is very low due to tax evasion and avoidance problems. Investible profits of public enterprises are negligible due to their operational inefficiencies and social objectives. There is twin gap: saving - investment and trade gap in Ethiopia Tadese (2011).

When we see the Ethiopian case where the economy is characterized by: by low human development index (0.392\%), relatively low life expectancy (59 years), low road density (4 km of road per $100 \mathrm{sq} \mathrm{km}$ ), low telecommunication service ( 0.97 per 1000 people) and low electric consumption (54 kwh per capita) requires huge investment to overcome those problems. But financing those investments through domestic resource mobilization is impossible because the country's financial system is underdeveloped and characterized by: low population to financial service coverage, Low percentages of adults which have accesses to formal credit (1.197\% in 2006 and has increased to $1.86 \%$ in 2011), low number of depositors in commercial banks (was only 65.97 per 1,000 people in 2006 and has increased to $114.76 \%$ in 2010 , low population-to-branch ratio (one branch for 62,063.6 people). Similarly the taxing system is also underdeveloped and with low tax to GDP ratio (only 9.28\%), and low saving to GDP ratio only 15\%.Therefore the government did not have any alternative other than borrowing from abroad to finance its huge investments. For this reason the country's external debts has been increasing from time to time and have its own impact on domestic economy.

The contribution of External debt on economic growth remains a debated issue by both academicians and policy makers. Currently, there have been attempts to answer the question of whether the rising external debt stock shows positive or negative contribution on the growth rate of 
an economy, but most of them end up with controversial conclusion and their findings are mixed at best. Significant number of researchers mentioned in their research work that there exists a negative relationship between external debt and economic growth; Cristina Checherita et al (2010), Vighneswara Swamy (2015), while other researchers such as Mencinger et al (2014), Markus Ahlborn et al (2016), Alfredo Schclarek (2004), Tilemahos Efthimiadis (2011) came up with the finding that external debt stock has a neutral as well as positive impact on economic growth. No doubt, governments borrow to fill the fiscal gaps in the proposed expenditure and expected revenue within a fiscal period on one hand and to avoid unfavorable conditions in macroeconomic stability which would otherwise happen by printing more money to fill the fiscal gap. To achieve these opposing goals, then debt option becomes the only available avenue that the government can look for to provide social overheads for its citizen.

However, many scholars argue that debt would only play a positive impact if it is stable. After the government debt exceeds a certain level, it will not remain a blessing to one's development. Excessive debt may depress the growth by limiting the productivity and weakening investment growth so developing countries are expected strive hard to achieve a sustainable economic growth. Therefore, these governments need to gain control over their expending fiscal deficit. In contrast to that, if the government debt is not sustainable, it will put the economic prosperity into a risky situation. Since it should be remembered that the debt also hints at a higher current account deficit, which means the debt most certainly could just as well lead to an unbalanced debt in a country. The debt for any economy is either a public or a publically guaranteed debt; it involves the contingent liabilities which play an important role in the cultivation of the entire economy. Developing countries usually have limited internal sources to yield their revenue. If they fail to utilize their debt productively, mobilize investment and create new employment opportunities; they will eventually get stuck up with the lower revenue base which in turn will affect their spending capacity, thereby leading to higher debt service payment. The inability to service debt on time not only makes it harder for developing countries to get aid at concessional rates with less conditionality's from donor agencies, but it also increases the country's risk. (Yunheqiu, 2010).

Even though some studies had been conducted in the past on the relationship between external debt and economic growth in Ethiopia. They lack the following respects. First, most of the previous studies did not separate the debt burden into total external debt stock and total external debt servicing. In this paper, the effect of public external debt is separated into total stock of public external debt effect and repayment or servicing of public external debt effect. In addition, the causal relationship of these variables with economic growth is examined.

Moreover, previous studies is that most of them are used Johanson co-integration method of vector autoregressive method as their method of analysis. Even though the Johnson's Co-integration technique is one of the widely used methods of time series analysis, its outcome could not be reliable for small sample size; that is observations less than eighty years for the time series data (Narayan, 2005; Udoh et.al, 2012). Relatively, the Autoregressive distributed lag (ARDL) method has some advantage over the Johnsons method (Pesaran et al., 1999). These advantages are it can be applied irrespective of whether the regressors are I(1) and I(0). It can also provide valid and statistically significant result or avoids the problem of biasness in small sample sizes (Pesaran et al., 1999, Narayan, 2005; Chaudhry et.al, 2006 and Udoh et.al, 2012). This ARDL procedure can provide unbiased and valid estimates of the long run model even when some of the regressors are endogenous (Harris et.al, 2003, Pesaran et.al, 1999, Ang, 2007). Furthermore, in using this Approach, a dummy variable can be included in the co-integration test process, which is not permitted in Johansen's method (Rahimi et.al, 2011). Hence in this paper, ARDL model is used to provide valid empirical evidence on the main target of this study which is assessing the impact of public external debt on economic growth in Ethiopia.

The overall objective of this study is to examine the causal linkage between external debt and economic growth in Ethiopia. More specifically the study aims: To empirically examine the effect of external debt (both its stock and its servicing) on the aggregate economic growth of Ethiopia in both short run and long run, using ARDL bound test approach, to examine the nature and direction of causation between external debt and economic growth through Granger's causality test for Ethiopia and to suggest appropriate policy options on the basis of the empirical findings.

The reminder of the paper is organized as follows. Section 2 includes review of the related literature while section 3 provides data and descriptive statistics and section 4 reports on the findings and discussion of results. Section 5 concludes the paper. 


\section{Literature review}

\section{External debt}

External debt is defined as an obligation of a government to make payments of specified amount to holders of the debt instrument. During the process of undertaking the debt the government receives command over resources in exchange for its promise to make future payments, those future payments include interest plus principal payments (Buchanan, 2005). The focus of this study will be only on external debt which can be defined as, government plus governmentguaranteed external debt and capital formation.

Likita (2000) defined debt as a contractual obligation of owing or accumulated borrowing with a promise to payback at a future date. Every economy requires an amount of capital to generate production and sustain development: capital, being a factor of production is particularly important but relatively scarce, and the dearth of capital is much more prevalent in developing countries.

External debt problem facing sub-Saharan African nations over the period, the following three major interdependent factors were found to be contributing to the accumulation of external debt.

The first is the trade policy. External debt should pursue trade policies that would result in significantly large export earnings to meet additional debt obligations or to reduce the total stock of external debt in the long term. the second is macroeconomic policy. Unsustainable expansionary monetary policy can result in a chronic current account deficit and fiscal imbalance leading to a buildup of external debt, the third is external and global shocks. This accounts for the contribution to external debt from factors beyond the direct control of policymakers in low-income countries, ( Siddique ,1996).

\section{Debt overhang effect}

A country's debt is said to be over hanged when a stock of external debt exceeds a country's capacity of repayment and resulted in debt arrears. This higher debt serving obligation enforces the government to impose higher taxes on the private sector to supplement the shortfall of repayment per contractual agreement. Higher taxes, in turn, reduce the incentive to save, invest, and engage in productive efforts. Therefore, resources that might have funded for investments are consumed by debt servicing (Claessens, 1990).

Debt overhang exists when the country's debt service burden is so heavy that a large portion of the current output accrues to foreign lenders which consequently creates disincentive to invest as a result of tax disincentive and macro-economic instability. Tax disincentive means that a large debt stock discourages investments; because investors assume that there would be taxes on future income in order to make debt repayments. The macroeconomic instability relates to increases in fiscal deficit, uncertainty due to exceptional financing, exchange rate depreciation, possible monetary expansion, and anticipated inflation ( Sachs, 2002).

In general, a debt overhang occurs when countries have higher external debt to GDP ratio, and when they have relatively less funds available to provide conducive environment for business and promote investment, which further deteriorate the current level of economic growth. A debt overhang discourages domestic investment, and can delay private capital flows required to generate sustainable growth (Bangura, 2004). Debt overhang also results in disincentive investments in human capital and new technologies, and the government's willingness to adopt structural reforms and fiscal adjustments, leading to poverty trap (Sachs, 2002).

\section{Crowding out effect}

Liquidity and solvency of countries are important indices in dealing with external debt impacts on economic growth (Ajayi, 1991). A liquidity constraint refers to the inability of a country to service its debts now in the amount initially contracted, due to lack of enough cash on hand to repay current obligations. While, the solvency refers to whether the value of a country's liabilities exceeds the ability to pay at any time; it also includes of incapability of country servicing its debt in the long run (Ajayi, 1991). If a country debt-service ratio and the debt-GDP ratio are high, the country will be illiquid and its ability to remain solvent will also be impaired. Therefore, the county needs to pursue accelerated growth in order to reduce its debt problems, and more importantly, to break out of its low-income status.

A liquidity constraint represents a 'crowding out' effect of external debt. An increase in external debt servicing reduces funds available (export earning) and leaves less avenues for expansion of investments. It indirectly also affects a country's ability to borrow further from external 
resources, thereby, put pressure on domestic borrowing and leading to crowding out (Taylor,1994). This liquidity constraint negatively affects a private investment as well a public and publicly guaranteed investments. The damaging impact of debt servicing on growth is attributable to the reduction of government expenditure, resulting from debt-induced liquidity constraints. a liquidity constraint which arises from the increase in debt servicing requirements may shift the budget away from the social sector or public investment to meet debt obligation. He underlined that public expenditure is a major determinant of the economic activities in many functional sectors. He also argued that debt can additionally influence economic growth via its effect on the productivity of investment and decrease output growth by diminishing productivity and as a result of the adverse changes in investment. Thus, crowding out effect discourages capital formation and encouraging capital flight due to tax increase expectation (Cohen, 1993).

\section{The growth-cum-debt models}

The basic argument to the growth-cum-debt model is that a country will be able to service its debt provided the debt leads to more growth. This means that a country will only borrow if the borrowed funds help it to improve its economy. External borrowing will be determined on whether such borrowing affects economic growth. The amount of money does not quantify the value of debt but on the effects the debt will have on the economy of the country. The growth-cum-debt models consider debt capacity in terms of the benefits and costs of borrowing in the process of economic growth

\section{Debt and economic growth}

The existing literature on the analysis of public debt and economic growth tends to indicate a negative relationship. According to Modigliani (1961) and Buchanan (1958), public debt is a burden to future generations because it reduces the stock of private capital, which in turn reduces the flow of income. Specifically, public debt can negatively impact economic growth by crowding out private investments. If the proportion of government operations funded through debt is significantly high, interest rates may substantially increase in the long-run. An increase in debt will not be costless to future generations despite benefiting the current generation.

Modigliani (1961) say that gross burden of public debt can only be offset in part or in total if borrowed funds are used to finance productive public capital formation, which in turn improves the real income of future generations. The interest accruing from both domestic and external debt is often paid through taxes. This reduces the available lifetime consumption of taxpayers and their savings. As a result, capital stock and economic growth reduce.

According to Krugman (1988), external debt affects economic growth through its adverse effects on investments. As domestic and foreign investors reduce their supply of capital, the level of investment reduces. This leads to a reduction in economic growth. Public debt can also negatively affect economic growth through higher future distortionary taxation, inflation, and greater uncertainty about prospects and policies. Extreme cases of debt crisis can also trigger a banking or currency crisis; thus, causing a reduction in economic growth.

Krugman (1988) coined the term debt overhang to describe the negative relationship between public debt and economic growth. Debt overhang refers to when the ability of a country to repay its external debt reduces below the contractual value of the debt. Cohen (1993), on the other hand, argues that the relationship between public debt and economic growth is non-linear. This means that an increase in external public debt promotes investment up to a certain level or threshold. Beyond the threshold, debt overhang will discourage investors from providing capital to the government. Eventually, economic growth begins to decline as interest rates increase. High public debt can affect economic growth negatively through different channels. One of the most important channels is longterm interest rates.

\section{Empirical literature review}

Literature review on the impact of foreign loans on economic growth shows that there are different groups: The first group follows the traditional school who believe that external borrowing has a positive impact on the economies of developing countries. This school argues that the cause of low levels of development in developing countries is the decrease in national savings and the balance of foreign currency which cause developing countries to suffer two gaps: Saving Gap and Foreign Currency Gap. (Chenery \& Carter, 1973). 
The second group argues that the impact of debt is very weak on national income and economic growth because of two reasons: First, debt lowers rates of domestic saving, since a large part of the loans and foreign aid is used to increase the level of consumption and not to increase the volume of domestic savings. In addition, large portion of the loans and foreign aid were allocated for infrastructure and capital-intensive projects.

However, most scholars agreed that Threshold level of debt is best strategies either debt is better for economic growth and capital formation or not below that level, many scholar's debt is positively associated with growth, but above threshold debt becomes negative.

Barro (1979) contribution as a tax is smoothing and shows one mechanism by which external debt and deficits can be welfare improving. The crucial finding in Barro (1979) is that the social planner should keep the tax rate constant. The level of taxes is determined by the government's intertemporal budget constraint, which says that the present value of spending, which is exogenous in the model, has to be equal to the present value of taxes.

Empirical studies on debt-economic growth relationship are numerous in the literature in both Developed and developing countries. Theoretically, it is expected that the marginal product of Capital should be higher than the world interest rate for developing countries. Then, such Countries would benefit from external borrowing (Eaton, 1993). However, external debt only helps to exploit the potentials of a country, it does not enhance it. Therefore, the only guideline is that the rate of return on spending should exceed the marginal cost of borrowing on the Assumption that debt is paid (Indermit and Brian, 2005).

Pattillo (2003) apply a growth accounting framework to a group of 61 developing countries in sub-Saharan Africa, Asia, Latin America, and the Middle East over the period 1969-98. Their results suggest that on average, doubling debt reduces by almost 1 percentage point both growth in per capita physical capital and growth in total factor productivity. Moreover, the policy environment also affects the debt/growth relationship.

Lyoha and Milton (1999) used simulations approach to study the impact of external debt on economic growth in sub-Saharan Africa for the period 1970 to 1994 and found that the external debt lowers the investment thus adversely affect economic growth.

Krugman (1988) defines debt overhang as a situation in which the expected repayment on external debt falls short of the contractual value of debt. If a country's debt level is expected to exceed the country's repayment ability with some probability in the future, expected debt service is likely to be an increasing function of the country's output level. Thus, some of the returns from investing in the domestic economy are effectively "taxed away" by existing foreign creditors, and investment by domestic and foreign investors and thus economic growth is discouraged. In its original formulation, the debt overhang theory centered on the adverse effects of external debt on investment in physical capital. The scope of the theory is, however, much broader: a high level of external debt can also reduce a government's.

Adepoju,(2007) found that the accumulation of foreign debt hinders economic growth in Nigeria. In addition, Mallik et al. (2010) found that the external debt and debt service have a negative impact on economic growth in Pakistan during the period 1972 to2002. Hameed et al. (2008) also found negative relationship between the external debt, equity capital, and manpower and the economic growth in Pakistan for the period 1976-2003.

Jayaraman and Evan (2008) study confirmed that the high flow of aid and foreign debt has contributed significantly to high rates of economic growth in the six countries of the Pacific during the period 1988 to 2004 .

On another study of the external debt on the Jordanian economy, Abdulhadi (2013) concluded that there is a negative impact of external debt on each of the economic growth, consumption, domestic savings, investment, and the balance of trade, both exports and imports.

Teklu(2014) study tried to analyze the effect of external debt on economic growth in the economy of Ethiopia. The result revealed that in the long run the model establishes a stable relation with negative and significant coefficient, therefore in the long run the model moves towards equilibrium. In Ethiopia, external debt as percentage of GDP has a negative and significant relationship with real GDP in the long run and no significant effect in the short run. And external debt as percentage of export has positive and significant effect on real GDP in the long run and no significant effect in the short run. The control variables investment and saving as percentage of GDP have positive and significant effect on both real GDP and capital formation in the short run

and in the long run. Therefore, the results strongly confirm that external debt have no effect in the short where as there is some implication of the existence of "Debt Overhang effects" in the long run. On the other hand, only in the short run inflation and openness did not have any effect on growth and capital formation whereas investment, saving have positive and significant effect. In this study government is advised to balance its revenue and expenditure, monitor external sector public borrowing and enhance improve its export item and volume for enhanced debt servicing capacity. 
In the work of Bakare (2011) asserted that capital formation influences the economic welfare of a country. It helps in meeting all the requirements of an increasing population in developing economy. It leads to the proper exploitation of natural resources and the establishment of different types of industries, levels of increase and the varied wants of the people are satisfied. They consume a variety of commodities; their standard of living rises and their economic welfare increases. Capital formation raises the level of national income. Bakare, (2011) using cointegration to ascertain the relationship between capital formation and economic growth, his result showed that capital formation has a direct relationship with economic growth of Nigeria.

\section{Methodology of the study}

For the purpose of analyzing the impact of external debt on economic growth in Ethiopia, secondary data for 48 years' annual data for the variables of interest which covered from 1970 to 2017, will be used. The data for the problem under investigation would be collected from Ministry of Finance and Economic Development (MOFED), National Bank of Ethiopia (NBE), United Nations Conference on Trade and Development (UNCTAD) and World Bank (WB). The time period 19702017 is chosen on the basis of the data availability on all the variables that also broadly includes two regimes, Derg and the present regime. The year 1991 has been chosen as the break year on the basis of regime change.

\section{Theoretical framework and model specification}

The theoretical foundation of the study is based on the augmented Solow model and endogenous growth model for economic growth equation which aims to show the impact of public external debt on economic growth of Ethiopia. It is constructed based on the theoretical framework of the augmented Solow Model and endogenous growth model with a modification that extends the basic production function framework to permit human capital as an additional input in to the production function following Romer (1996) and Debt burden following Cunningham (1993). As implied by Solow's formulation, economic growth is a function of capital accumulation, an expansion of labor force and exogenous factor, technological progress which makes physical capital and labor more productive. According to the endogenous growth model, human capital influences economic growth as:

$$
Y=f(K, H K, L F, A)
$$

Where $Y=$ is a proxy for economic growth, $K=$ Capital stock, $H K=$ Human Capital, $L F=$ Labor force and $A=$ technology.

According to Karagol (2002) if a country has significant debt burden, the need to service its debt will affect the employment of labor and capital in the production function and through its effect on the productivity of capital and labor economic growth will be affected. In the model of Shabbir and Yasin (2015) also highly indebted countries have to set aside a sizeable fraction of their scarce resources to service their debt, which naturally affects their development spending. Therefore, it is necessary to know the magnitude of relationship of growth with the debt service liabilities and the debt burden should be decomposed to public external debt stock and public external debt servicing. Then the extended model is given by:

$$
Y=(K, H K, L F, E D, D S, A, D u)
$$

Where: $Y=$ A proxy for economic growth, $K=$ Capital stock, $H K=$ Human Capital, $L F=$ Labor force, $E D=$ external debt stock, $D S=$ external debt servicing and $D u=$ a dummy variable for a policy change.

Expressing the variables in natural logarithmic form, an attempt will be made to look at the relative contribution (elasticity) of each variable to the growth process. The log-linear form of specification enables the researcher to interpret the coefficients the directly as elasticity (Sarmad, 1988). In addition, it is also useful for accommodating the heteroskedasticity problem (Goldstein et al., 1976). Then the empirical model of economic growth can be expressed as:

$$
L n R G D P_{t}=\beta_{0}+\beta_{1} L n E D_{t}+\beta_{2} L n D S_{t}+\beta_{3} L n T O_{t}+\beta_{4} L n P C_{t}+\beta_{5} L n H C_{t}+\beta_{5} L n L F_{t}+D u+U i
$$

Where: $\beta_{0}, \beta_{1}, \beta_{2} \ldots \beta_{5}=$ Parameters 
$R D G P t=$ Real GDP at time $t$

$E D=$ total stock of external debt at time $t$

$D S=$ external debt servicing as a percentage of export of goods and services at time $t$

TO $=$ Trade openness at time $t$

$P C=$ Capital stock proxied by private capital formation as share of GDP at time $t$

$H C=$ Human Capital proxied by secondary school enrollment as a percentage of gross

$L F=$ Labor Force as share of Total Population at time $t$

$D u=$ Dummy variable for the policy change

$U i=$ Error term

Ln=Natural logarithm

\section{Description and expected signs of the variables}

RGDP: This paper used real GDP as proxy for economic growth, which is the total market value of all final domestically produced products at constant price.

ED: Stock of external debt which is the targeted variable in this study can affect the economic growth in different ways. Shuaib et.al, (2015) reveals that the gross public investment includes investment by government and/or public enterprises financing through external borrowing. Hence, external borrowing is correlated positively with public investment. On the other hand, according to Krugman (1988), external debt acts as a major constraint to capital formation in developing nations by discouraging investment if this borrowing is not used for productive purposes. Therefore, stock of external debt is expected to have either positive or negative impact on the economy.

DS: external debt servicing is also another main targeted variable in this study and it is assumed to have negative effect on economic growth. Rockerbie (1996), and Cunnigham (1993) state that when a government has a substantial external debt burden, the manner in which labor and capital will be exploited in the production process is bound to be influenced by the need to service that debt. Karagol (2002) and clements et al. (2003) argued that external debt service burden has a negative impact on investment and capital accumulation. Hence, mixed result is expected.

T0: trade openness is the sum of export and import divided by GDP and expected to affect economic growth positively. Romer, (1993) claimed that the countries have higher possibility to implement leading technologies from other countries if countries are more open to trade. In addition, chang et.al (2005) emphasized trade openness promotes the efficient comparative advantage which allows the dissemination of knowledge and technological progress and encourages competition in the international market.

PC: Capital stock is defined as the value of the existing supply of physical goods that are used in the production process at a given point of time and includes buildings, machinery, equipment and inventory. There are points of view that capital stock is generally believed to be of critical importance, not only as a component of final aggregate demand, but also in terms of the impact of capital stock on the economy's growth and employment opportunities (Ghali, 1999). Hence, we expect that gross capital formation should have a positive coefficient in explaining economic growth.

HC: In this study human capital is proxied by gross enrollment ratio of secondary school enrollments as a \% of gross. Romer (1996) and Gungor (1997) notes that human capital which describes the knowledge and skills embodied in individuals are an important source of economic growth. Therefore, human capital variable is expected to have positive impact on the production and economic growth of the country.

LF: In this study the labor force is defined as the employed and unemployed labor force. Labor force comprises people ages 15 and older who supply labor for the production of goods and services during a specified period. Since the rate of utilization of the labor force is important in production, we expect a positive relationship between economic growth and labor force. But if it couldn't be used efficiently it may be a burden for the economy because of high rate of unemployment.

Du: Changes in political and economic policies (the dummy variable Du in the model) can influence the performance of the economy through investment on human capital and infrastructure, improvement in political and legal institutions and so on (Easterly, 1993).

\section{Method of estimation}

Most of the time series studies in this area previously conducted are used the Eangle Granger approach following Engle and Granger (1987) and the Johnson's Co-integration technique following Johansen (1988) and Johansen and Juselius (1990). But its outcome could not be reliable for small sample size (Narayan, 2005; Udoh et.al, 2012). Relatively, the Autoregressive distributed lag method of co-integration (ARDL) has more advantage over the Johnsons method (Pesaran et al., 1999). 
Johansen co-integration techniques require that all the variables in the system to have equal order of integration, that is the application of the Johansen technique will fail when the underlying regressors have different order of integration, especially when some of the variables are I(0) (Pesaran, et.al, 2001). That means the Trace and maximum Eigen value tests may lead to erroneous co-integrating relations with other variables in the model when $I(0)$ variables are present in the system (Harris, 1999).

Fortunately, to overcome this problem a new Autoregressive Distributed Lag (ARDL) model is developed by Pasaran, Shin and Smith (2001) which have more advantages than the Johnson cointegration approach. First, the ARDL approach can be applied irrespective of whether the regressors are $I(1)$ and $I(0)$ or have a mix of these integration orders. The only exception is that none of the variables in the model is integrated of order 2 or higher. Second, while the Johansen cointegration techniques require large data samples for validity, the ARDL procedure provides statistically significant result in small samples (Pesaran et al., 1999; Narayan, P., 2005; Udoh et.al, 2012). That means, it avoids the problem of biasness that arise from small sample size (Chaudhry et.al, 2006). Third, the ARDL procedure provides unbiased and valid estimates of the long run model even when some of the regressors are endogenous (Harris et.al, 2003, Pesaran et.al, 1999, Ang,J.,2007).

Moreover, the ARDL procedure employs only a single reduced form equation, while the other co-integration procedures estimate the long-run relationships within a context of system equations. Further, in using the ARDL approach, a dummy variable can be included in the co-integration test process, which is not permitted in Johansen's method (Rahimi et.al, 2011). Therefore, in order to achieve the targeted objectives of the study, the model of economic growth equation is estimated using ARDL model of econometric technique.

The above advantages of the ARDL technique over other standard co-integration techniques justify the application of ARDL approach in the present study to investigate the link between economic growth and external debt.

\section{Estimation procedure}

\section{Unit Root test}

The ARDL approach to co-integration does not require the pre-testing of the variables, included in the model, for unit root unlike other techniques such as the Johansen approach (Pesaran et al., 2001). However, Ouattara (2004) argues that in the presence of I(2) variables the computed F statistics provided by Pesaran et al. (2001) are no more valid because they are based on the assumption that the variables are I(0) or I(1); therefore, the implementation of unit root tests in the ARDL procedure might still be necessary in order to ensure that none of the variables is integrated of order two or beyond. Therefore, in order to determine the degree of stationarity, a unit root testing will be carried through the Augmented Dicky-Fuller (ADF) test and Philips and Perron (1988).

\section{Long run co-integration and the Error Correction Model}

The ARDL approach requires three steps. The first step is to check the existence of long run relationship among the variables of interest that is determined by F- test. The second step requires the estimation of long run relationship and to determine their values, thereafter the short run elasticity of the variables with error correction representation of the ARDL model. The purpose of applying the error correction version of the ARDL model is to determine the speed of adjustment to the equilibrium. Meaning that the ECM estimates the speed at which our dependent variable returns to the equilibrium given the change in the independent variable.

The ARDL bounds test modeling involves estimating the following unrestricted error correction model (VECM) using OLS.

$$
\Delta \mathrm{Z}_{t}=\alpha_{\mathrm{o}}+\sum_{i=1}^{k} \beta^{\prime} \Delta Z \mathrm{t}-1+\sum_{i=1}^{k} \delta^{\prime} \Delta W \mathrm{t}-1+\phi_{1}{ }^{\prime} \mathrm{Z}_{\mathrm{t}-1}+\phi 2^{\prime} \mathrm{W}_{\mathrm{t}-1}+\mathrm{Ut}
$$

Where $\Delta$ refers to first difference operator, $t Z$ vector of dependent variables, $W$ vector of $\mathrm{k}$ determinants of $t Z$ and $U t$ refers to residual error term which is assumed to be white noise having mean zero and variance covariance of $\delta^{2}$.

In order to do the bound test, the ARDL model to be used in this study can be specified as:

$$
\begin{aligned}
& \Delta L n R G D P_{t}=\alpha_{0}+\beta_{1} \operatorname{LnRGDP_{t-1}}+\beta_{2} L n E D_{t-1}+\beta_{3} L n D S_{t-1}+\beta_{4} L n T O_{t-1}+\beta_{5} L n P C_{t-1}+ \\
& \beta_{6} L n H C_{t-1}+\beta_{7} L n L F_{t-1}+\sum_{i=1}^{p} \delta_{1} \Delta L N R G D P_{t-i}+\sum_{i=1}^{p} \delta_{2} \Delta L n E D_{t-i}+\sum_{i=1}^{p} \delta_{2} \Delta L n D S_{t-i}+ \\
& \sum_{i=1}^{p} \delta_{3} \Delta L N T O_{t-i}+\sum_{i=1}^{p} \delta_{4} \Delta L N P C_{t-i}+\sum_{i=1}^{p} \delta_{5} \Delta L N H C_{t-i}+\sum_{i=1}^{p} \delta_{5} \Delta L n L F_{t-i}+\gamma D u+\varepsilon_{t}
\end{aligned}
$$


Where $\beta_{1}, \beta_{2}, \beta_{3}, \beta_{4}$ and $\beta_{5}$ characterizes the coefficients of the short run dynamics of the model whereas $\delta_{1}, \delta_{2}, \delta_{3}, \delta_{4}$ and $\delta_{5}$ coefficients show the long run relationship. In order to test the presence of long run relationship between the underlying variables, the above equations are estimated using OLS. To test the significance of lagged levels of the variables in this study, the appropriate test statistics is the familiar F or Wald test under the generalized Dickey-Fuller types of regressions in an unrestricted error correction regression.

The $H_{0}$ to be tested on equation (6) is

$$
H_{0}: \beta_{1}=\beta_{2}=\beta_{3}=\beta_{4}=\beta_{5}=0
$$

The alternative hypothesis $\left(H_{1}\right)$ against the null is given as

$$
H_{1}: \beta_{i} \neq 0
$$

The asymptotic distribution of the $\mathrm{F}$ or Wald statistics is non-standard under the null hypothesis of no long run relationship. Two sets of critical values are developed by Pesaran et al (2001) for two polar cases which assume that all the regressors are on one hand purely integrated of order one and on the other hand all are purely integrated of order zero. Since these two sets of critical values provide critical value bounds for all classification of regressors into purely I(1) and/or purely I(0), they proposed bound testing procedures. If the computed Wald or F-statistic falls outside the critical value bounds, a conclusive inference can be drawn without needing to know whether the underlying regressors are I (1), co-integrated among them or are individually I (0). To be specific, if the computed F statistic is greater than the upper bound critical value, we reject the null hypothesis of no long run relationship. If, however, the computed F statistics is less than the lower bound critical value, we fail to reject the null hypothesis.

This study rather used the critical values developed by Narayan (2004) which is based on small sample size between 30 and 80 observations.

After checking and confirming the existence of long-run relationship among all the dependent and independent variables, the following stable long-run model can be estimated:

$$
L n R G D P_{t}=\alpha+\beta_{1} L n E D_{t}+\beta_{2} \operatorname{LnDS}_{t}+\beta_{3} \operatorname{LnTO}_{t}+\beta_{4} \operatorname{LnPC} C_{t}+\beta_{5} L n H C_{t}+\beta_{5} \operatorname{LnLF}+D u+U_{t}
$$

After checking the co- integration relationship among the variables and estimating the long run model, the standard error correction model can be estimated as follows:

$$
\begin{aligned}
& \Delta L n R G D P_{t}=\alpha_{0}+\sum_{j=0}^{n} \beta_{1} \Delta L n R G D P_{t-i}+\sum_{j=0}^{n} \beta_{2} \Delta L n E D_{t-i}+\sum_{j=0}^{n} \beta_{3} \Delta L n D S_{t-i}+ \\
& \sum_{j=0}^{n} \beta_{4} \Delta L n T O_{t-i}+\sum_{j=0}^{n} \beta_{5} \Delta L n P C_{t-i}+\sum_{j=0}^{n} \beta_{6} \Delta L n H C_{t-i}+\sum_{j=0}^{n} \beta_{2} \Delta L n L F_{t-i}+\gamma D u+\delta E C T t-1+ \\
& \varepsilon_{t}
\end{aligned}
$$

$\beta_{1 j}, \beta_{2 j}, \beta_{3 j}, \beta_{4 j}, \beta_{5 j}$ and $\gamma$ are Coefficients that represents the short run dynamics

$E C T$ is an error correction term lagged by one period

$\delta$, is error correction parameter that measure the speed of adjustment towards the long run equilibrium after a short-run disturbance.

The error correction term (ECT) is derived from the corresponding long run model whose coefficients are obtained by normalizing the equation.

\section{The causality tests}

The presence of cointegration alone does not indicate the direction of causality. Hence, we need to test whether the relationship between the variables is unidirectional or bidirectional. Since the underlying series (LnRGDP and LnED) are integrated of the same order, the ordinary Granger causality test can be applied to perform causality tests. The test proceeds in estimating the following two equations.

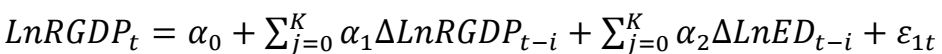

$$
\begin{aligned}
& L n E D_{t}=\beta_{0}+\sum_{j=0}^{K} \beta_{1} \Delta L n E D_{t-i}+\sum_{j=0}^{K} \beta_{2} \Delta L n R G D P_{t-i}+\varepsilon_{2 t}
\end{aligned}
$$

The null hypothesisis that:

H0: $\beta 11=\beta 12=\ldots=\beta 1 j=0$ Implying LnED does not Granger Cause LnRGDP

H1: $\beta 11 \neq \beta 12 \neq \ldots \neq \ldots \beta_{1} \neq 0$ Implying LnED does Granger Cause LNRGDP 
The null hypothesis can be stated as:

H0: $\alpha 11=\alpha 12=\ldots=\alpha 1 j=0$ Implying LnRGDP does not Granger Cause LnED

H1: $\alpha 11 \neq \alpha 12 \neq \ldots \neq \alpha 1 \mathrm{~J} \neq 0$ Implying LnRGDP does Granger Cause LnED

The decision is that there is causality from external debt (LnED) to economic growth (LnRGDP) if the null hypothesis $H 0: \beta 11=\beta 12=\ldots .=\beta 1 j=0$ can be rejected at least at $10 \%$ level of significance in the case of equation 16 . Similarly, there is causality from economic growth to external debt if the null hypothesis $H 0: \alpha 11=\alpha 12=\ldots . .=\alpha 1 j=0$ can be rejected at least at $5 \%$ level of significance in the case of equation 17.

\section{Results and discussion}

\section{Empirical results for unit root testing}

It is vital and must to test the nature of stationarity of the variables before running ARDL model, a model used to determine the existence of long run relationship among the variables. Doing so avoids the possibility of running a spurious regression, which makes the result to be unreliable and inconsistent (See Appendix 1).

The result indicates that; from ADF test statistics the null hypothesis of unit root cannot be rejected for all variables in level. However, except human capital which is stationary at a level, every variable become stationary with trend once they are first differenced. This indicates that none of the above variables are integrated of order two (I (2)), which is a precondition to use ARDL model. In other words, there is no variable that is stationary in second difference and such result of the ADF unit root test is one justification for using the ARDL approach (bounds test approach of cointegration) developed by Pesaran, Shin, and Smith (2001).

The study had also applied the PP test for unit root. (See Appendix 2) and the result is similar with ADF test. Therefore, ARDL or bound testing approach to cointegration is the preferred and appropriate method of regression in this case.

\section{Bounds test for long run relationship}

In the ARDL approach to Cointegration, the first step is to test the presence of cointegration or long run relationship among the variables. This test for the long run relationship is done using the Fstatistic. Given the annual nature of the data; it is recommended that the optimal lag length for the ARDL model is maximum two lags. Moreover, AIC is used to determine the optimal lag because of small sample size at hand.

The F-test statistics, which is derived from this regression output, tests the joint null hypothesis that the coefficients of lagged level variables are zero meaning; there is no long run relationship. The F statistic will then be compared with the lower and upper bounds of Kripfganz and Schneider (2018) critical values, based on the rational mentioned in chapter three (See appendix 3).

As result indicates, the calculated F-statistics is $\mathbf{8 . 0 9 5}$ and this value is higher than the upper bound critical values at $5 \%$ level of significance. The results indicate that there is strong evidence of long-run relationship or co-integration between log of RGDP and the remaining variables. This represents a co-integrated RGDP equation in Ethiopia. Thus, the null hypothesis of no co-integration between log of RGDP and its fundamentals is rejected.

\section{Diagnostic testing and model stability}

To check the reliability and verifiability of the estimated long-run and short-run models, diagnostic tests are undertaken. These tests include serial correlation (Brush and Godfray LM test), Functional form (Ramsey's RESET test), Normality (Jaque-Bera test), Hetroscedasticity (BreuschPagan-Godfrey test) and also CUMSUM recursive residuals and CUMSUM square recursive residuals tests are applied to check the overall stability of the long-run and short-run coefficients which are recommended by Pesaran et al. (2001). Finally, the result from indicates that, the model doesn't suffer from heteroskedasticity problem, no serial correlation, correctly specified and the error term is normally distributed (See Appendix 4).

As the two plots above clearly reveal the plots of CUMSUM and CUMSUMSQ stay within the lines, and, therefore, this confirms the equation is correctly specified and the model is stable. Furthermore, the result shows that there is no structural instability in the model during the sample period. From this, the model appears to be robust in estimating short run and long run relationship between real gross domestic product and the included explanatory variables. (See Appendix 4). 


\section{Dynamic long-run ARDL estimates}

Based on the confirmation obtained from the unit root test about the absence of a variable which is integrated of order two and given the F statistic result which indicated the existence of long run cointegration among the variables (log of real GDP, log of total external debt, log of external debt service log of trade openness, log of human capital, log of physical capital, log of labor force and policy change dummy), it is now possible to proceed to the estimation of the long run coefficients of the model. The following table presents the results found after running the appropriate ARDL model to find out the long run coefficients. The figures in bracket are number of lags chosen by the model for each variable.

\begin{tabular}{lcccc} 
Table 1: Estimated long run coefficients using the ARDL approach & \\
\hline Regressors & Coefficient & ST. Error & T-Ratio & Prob. Value \\
\hline LnED & -0.256 & 0.126 & -2.11 & $0.043^{* *}$ \\
LnDS & 0.154 & 0.142 & 1.091 & 0.286 \\
LnTO & -0.324 & 0.193 & -1.670 & 0.105 \\
LnPC & 0.343 & 0.073 & 4.691 & $0.000^{* * *}$ \\
LnHC & 0.516 & 0.250 & 2.061 & $0.048^{* *}$ \\
LnLf & 0.075 & 0.134 & 0.560 & 0.578 \\
Du (Policy Change dummy) & 0.561 & 0.239 & 2.35 & $0.026^{* *}$ \\
Constant & 2.68 & 0.51 & 5.25 & $0.000^{* * *}$ \\
\hline
\end{tabular}

Note: The signs ${ }^{* * *},{ }^{* *}$ and $*$ indicate the significance of the coefficients at $1 \%, 5 \%$ and $10 \%$ level of significance respectively.

The real GDP equation or growth model is specified in a log-linear form; hence, the coefficient of the dependent variable can be interpreted as elasticity with respect to economic growth. As we observe from the long-run ARDL regression result (see Table 4.6), log of total external debt has a significant negative impact on log of GDP per capita and a 1\% rise in the stock of external debt, keeping other things constant, leads to a $0.256 \%$ decline in real GDP. This significant negative impact of total external debt on economic growth implies that, the greater the level of stock of external debt, the more the economic growth worsens. This result partly reflects the use of external borrowing (except capital linked loans) on non-productive activities and sectors and this is consistent with the literature. Moreover, a significant portion of external debt proceeds to repay other past external debts rather than to boost capital investment in domestic. This result is in line with the finding that high external debt levels are associated with low growth as a higher tax burden on capital is required to service this stock of external debt, leading to a lower rate of return on capital and hence lower investment, dead weight loss and sluggish economic growth.

Hence, the result reveals that the "debt overhang" theory and the "conventional view" of public external debt holds true for Ethiopia. It is inconsistent with the findings of studies made by Medina (2016) for Ethiopian economy, Al-Zeaud (2014) for Jordanian economy, Uzun, et al., (2012) for transition economies, Rahman (2012) for Malaysian economy, Okechukwu and Anele (2012) for Nigeria's economy. But it is in line with the results specifically those related to developing countries such as a study made by Peng Lee \& Ling Ng (2015) for Malaysian economy, Shabbir \& Yasin (2015) for developing countries, Kumar and Woo (2010) for advance and emerging economies.

Contrarily, as it has been shown on the above table, the coefficient of log of external debt servicing is insignificant in explaining log of real GDP in Ethiopia. Thus, there is no evidence to support the theory of a long-run "crowding-out" effect of public external debt. The result reveals that external debt servicing, that is fraction of the scarce resources which is transferred to foreign debt payment, does not affect the development spending and hence economic growth in Ethiopia. It is inconsistent with a study made by Shah and Pervin (2012) for Bangladish economy. Another variable employed in explaining the economic growth equation is physical capital (which is proxied by gross capital formation of the country). In the long run log of physical capital brought a very significant positive impact on log of real GDP. Holding other things constant, a $1 \%$ increase in physical capital could result a $0.343 \%$ increase in real GDP. This result supports the theory that an expansion and utilization of physical capital is important in production.

Moreover, log of human capital has a significant positive impact on log of real GDP of Ethiopia in the long-run. According to Romer (1996), human capital accumulation that is the ability of individuals to solve problems and to think critically is believed to promote higher growth. Hence, in this study this theory does hold true and a 1\% rise in human capital (proxied by secondary school enrolment as a share of gross enrollment), leads to $0.516 \%$ growth in real GDP. 
Also, the dummy variable for policy change (Du) was found to be significant in affecting economic growth (real GDP) in Ethiopia. Other things remains constant, a policy changes from Derg regime to post Derg regime leads to a $0.561 \%$ increase in real GDP of the country. This result is consistent with the descriptive analysis and it is due to structural adjustment policies, relatively favorable political condition, departure from the previous socialist system and good economic performance over the regime. However, trade openness (proxied by the ratio of export and import on GDP) and labor force are found to be insignificant in the model (See Appendix 2).

\section{Short-run Error Correction Model}

The short-run ARDL estimate above indicates that, unlike that of the long-run analysis, stock of external debt (DLnED) is significant but with positive sign and it have an impact on economic growth (RGDP). This short-run finding is inconsistent with the study made by Shah and Pervin (2012) for Bangladesh economy. This is because the amount borrowed may be used optimally; it is expected to increase investment. Economic theory suggests that reasonable levels of borrowing by a developing country are likely to enhance its economic growth. (Krugman, 1988, Sachs, 1989a). Countries at early stages of development have small stocks of capital and are likely to have investment opportunities with rates of return higher than those in advanced economies. As long as they use the borrowed funds for productive investment and do not suffer from macroeconomic instability, policies that distort economic incentives, or sizable adverse shocks, growth should increase and allow for timely debt repayments.

Similarly, from the dynamic short-run result we observed that, external debt servicing (DlnDS) is insignificant and it has not observable effect in economic growth in Ethiopia. This short-run result of log of debt servicing is the same and consistent with the result in the long-run analysis. However, lag of debt servicing found to have positive and significant impact on economic progress of the country. As per the estimation result, the short run coefficient of external debt service is positive and significant at its lag. One percent increase in external debt service raises the rate of growth of real GDP by $0.0417 \%$ which is contrary to conventional theory. The result is not in line with (Fatai ,2016; Siddique and Selvanathan ,2015; lyoha 1999; Mulugeta ,2014;). The possible reason of this result may be due to the good reputation created for the country in the eyes of multilateral and bilateral creditors because of the continuous commitment to pay back its debt even in the bad situations. This may have facilitated a good economic environment for the country such as easy access to international capital markets, less cost of concessional loan and provision of trade credit from its creditors (Furceri \& Zdzienicka, 2012). In addition, the good reputation that Ethiopia had attracted further loan for productive investments, huge foreign aid, foreign direct investment and other development assistances that has a significant role for its growth.

Furthermore, its creditworthiness helped the country to find trade partners in the external market which might have helped the export performance to contribute more to the overall economic growth (Rose, 2005).

On the other hand, unlike the long run estimation result, labor force (DLnLf) found positive and statistically significant in the short run. Moreover, the policy change dummy (Du) found negative and statistically weak significant.

\begin{tabular}{|c|c|c|c|c|}
\hline Regressors & Coefficient & ST. Error & T-Ratio & Prob. Value \\
\hline dLnED & 0.0657 & 0.028 & 2.34 & $0.026^{* *}$ \\
\hline $\operatorname{dLnED}(-1)$ & 0.61 & 0.309 & 1.96 & $0.059 *$ \\
\hline dLnDS & 0.006 & 0.0229 & 0.000 & 0.998 \\
\hline $\mathrm{dLnDS}(-1)$ & 0.0417 & 0.017 & 2.37 & $0.024^{* *}$ \\
\hline dLnLf & 0.143 & 0.048 & 2.97 & $0.006^{* * *}$ \\
\hline dDu (Policy Change dummy) & -0.0116 & 0.065 & -1.77 & $0.087^{*}$ \\
\hline $\operatorname{ECM}(-1)$ & -0.2425 & 0.0786 & -3.08 & $0.004^{* * *}$ \\
\hline \multicolumn{5}{|l|}{$\mathrm{R}$-square $=84.1 \%$} \\
\hline Adj. $R^{2}=76.91 \%$ & & & & \\
\hline
\end{tabular}

The speed of adjustment of any disequilibrium towards long-run equilibrium or the equilibrium error correction coefficient (ECM), estimated (-0.2425) is highly significant and has the correct sign. It implies a high speed of adjustment to equilibrium after a shock. Approximately 24.25 
$\%$ of the disequilibrium from the previous year's shock converges back to the long-run equilibrium in the current year and such significant error correction term is another proof for the existence of a stable a long-run equilibrium relationship among the variables.

Regarding the short run model's goodness of fit, as the table 4.7 shows, the regression result imply that real gross domestic product is moderately explained by the explanatory variables incorporated in the model. The R-squared reveals that $84.1 \%$ of the short-run variation in real gross domestic product is explained by the explanatory variable (See Appendix 2).

\section{Granger causality test results}

Granger causality test provides important information of the causal direction between the variables and knowing the direction of causality between the variables. In this study, Granger causality Wald test after VAR model was employed to look at the causal linkages between economic growth and external debt in Ethiopia.

\section{Pairwise granger causality test}

This section is concerned with tests of Granger causality between RGDP and external debt stock. A variable is said to Granger cause another variable if past values of it help predict the current level of the other variable. Granger test is based on the concept of causal ordering. In this analysis Four patterns of causality can be distinguished: (a) unidirectional causality from one variable, let us say X to another variable Y; (b) unidirectional causality from Y to X; (c) feedback or bi-directional causality; and (d) no causality.

To identify the direction of causality between the dependent variable (LnRGDP) and the targeted independent variables stock of external debt (LnED) and external debt servicing (LnDS), a granger causality test is undertaken. The result revealed that, there is significant unidirectional causality between real GDP per capita and stock of public external debt (proxied by the stock of public external debt as a share of GDP) and public external debt servicing (proxied by public external debt servicing as a share of export of goods and services).

\begin{tabular}{|c|c|c|c|}
\hline $\begin{array}{l}\text { Pairwise Granger Causality Tests } \\
\text { Date: } 12 / 06 / 19 \quad \text { Time: } 02: 25 \\
\text { Sample: } 19702017 \\
\text { Lags: } 2\end{array}$ & & & \\
\hline Null Hypothesis: & Obs & F-statistic & Prob. \\
\hline LnED does not Granger Cause LnRGDP & 45 & 5.0475 & $0.0310^{* *}$ \\
\hline LnRGDP does not Granger Cause LnED & 45 & 2.0314 & 0.2147 \\
\hline LnDS does not Granger Cause LnRGDP & 45 & 3.1477 & $0.0483^{* *}$ \\
\hline LnRGDP does not Granger Cause LnDS & 45 & 0.4458 & 0.6439 \\
\hline LnED does not Granger Cause LnDS & 45 & 1.5204 & 0.2491 \\
\hline LnDS does not Granger Cause LnED & 45 & 4.0283 & $0.0196^{* *}$ \\
\hline
\end{tabular}

Note: The signs $* * *, * *$ and $*$ indicate the significance of the coefficients at $1 \%, 5 \%$ and $10 \%$ level of significance respectively.

There is a unidirectional causal relationship from stock of external debt to RGDP is consistent with the long-run regression result. The uni-directional relationship between RGDP and stock of external debt implies that stock of external debt causes only for RGDP change and real GDP doesn't cause stock of public external debt to change. This is inconsistent with the finding of study by Apere (2014) for the Nigeria's economy but it is consistent with Korkmaz (2015) for Turkish economy.

Another important result that is found from the Granger causality test is that there is a unidirectional Granger causality running from external debt service to external debt stock. This implies clearly that the more Ethiopia services its external debt, the more likely its stock of accumulated debt will be reduced. Therefore, this intuition explains that external debt Ganger causes the external debt stock by decreasing its amount. However, this can also have an opposite meaning that as the country continues to repay its debts and fulfill its obligations; its reputation in the eyes of its debtors is increased. And hence, additional access to loan from abroad is eased and as a result, the debt 
accumulation and debt servicing burden is further worsened unless the debt is managed well and used for productive purposes. (Feder, 1982; Rose, 2005; Furceri \& Zdzienica; 2012).

\section{Robustness check}

Our results are obtained using ARDL estimation technique. In order to test the robustness of our model specification and results, we used different lag selection criteria as robustness check mechanism. This is because ARDL very sensitive to the number of lags included for the variables in the estimation of the model.

To do so we estimated the same data using other lag selection criteria (Schwarz Bayesian Information criteria (SBIC)) and the result obtained in this modeling framework is compared to that of ARDL model (see appendix 3). They lead to similar outcome, that, there is negative and statistically significant relationship between economic and external debt in the long-run. Whereas, external debt stock (our variable of interest) is found significant and have positive effect on output, which is dissimilar to the long run result. Further, the dummy of policy changes statistically significant in both short-run and long-run. Also, the speed of adjustment of any disequilibrium towards long-run equilibrium or the equilibrium error correction coefficient (ECM), estimated $(-0.2524)$ is highly significant and has the correct sign.

Hence, our result is stable and robust across different lag selection criteria.

\section{Conclusion and policy implication}

This study aimed to examine the dynamic relationship between economic growth and external debt in Ethiopia. Under this objective this paper tries to achieve the following specific objectives: the trends of economic growth and external debt in Ethiopia, short-run and long-run effect external debt both in stock and servicing on economic growth and external debt and to examine the existence of causality between the variables so as to give policy implication.

In order to achieve objectives, data from different relevant source were collected over the years 1970 - 2017 and the parameters of the model were estimated using ARDL system of data estimation technique.

The unit root test result shows that all variables except human capital found non-stationary at level but they become stationary after first differencing I(1). ARDL bound test of cointegration show that there is long-run cointegration that there is long run association among the variables in case of Ethiopia.

The estimation result reveals that, external debt found statistically significant and positive in affecting economic growth in the long-run whereas debt servicing found statistically insignificant. However, external debt stock found negative and statistically significant in short-run. Also, the dummy variable incorporated to capture the policy change effect found significant both in long-run and short-run.

It is found that the error correction terms (ECM (-1)) is statistically significant. This indicates that there exists a long-run relationship among the variables $(-24.25 \%)$ which shows the speed of adjustment towards equilibrium and suggests a rapid speed of convergence to equilibrium.

Regarding the causality, there is a unidirectional causal relationship from stock of external debt to RGDP which is consistent with the long-run regression result. The uni-directional relationship between RGDP and stock of external debt implies that stock of external debt causes only for RGDP change and real GDP doesn't cause stock of public external debt to change. Another important result that is found from the Granger causality test is that there is a uni-directional Granger causality running from external debt service to external debt stock. This implies clearly that the more Ethiopia services its external debt, the more likely its stock of accumulated debt will be reduced.

From our major findings, we found the overwhelming negative impact of stock of public external debt on economic growth of Ethiopia. This increasing public external debt stock may lead the country towards high debt ratio regimes associated with lower economic growth.

Since the dependence on external resource is both risky and unreliable, the government needs to mobilize its own resource and need to pursue policies geared towards reducing its exposure to external debt stock in order to reduce its adverse effects on the economy. That is, to avoid more loans build-upping, the government should diversify the economy so as to generate more revenue and need to increase financing from the domestic market.

The government and policy makers should expeditiously seek to implement structural reforms geared towards public sector reform and public external debt sustainability. 
There is a need for the government and policy makers to know the threshold level of public external debt. Because reasonable borrowing can enhance economic growth, both through capital accumulation and productivity growth.

The government should pay more attention to the debt management profile particularly in its expenditure. Borrowed funds should be tied to productive ventures and invested in self-liquidating developmental projects investing including basic infrastructural developments that facilitate the productivity of other sectors of the economy rather than for social consumption.

\section{Reference}

Adepoju, A. A., Salau, A. S., \& Obayelu, A. E. (2007). The effects of external debt management on sustainable economic growth and development: lessons from Nigeria.

Ajayi, S. (1991). Macroeconomic approach to external debt: the case of Nigeria. Research paper/African Economic Research Consortium; 8.

Apere, T. 0. (2014). The impact of public debt on private investment in Nigeria: Evidence from a nonlinear model. International Journal of Research in Social Sciences, 4(2), 130-138.

Bangura, S., Powell, M. R., \& Kitabire, M. D. N. (2000). External debt management in low-income countries (No. 0-196). International Monetary Fund.

Barro, R. (1989). Economic Growth in a Cross-Section of Countries. NBER Working Paper Series, 3120, National Bureau of Economic Research, USA, September 1989.

Barro, R. J., \& Lee, J. W. (1994, June). Sources of economic growth. In Carnegie-Rochester conference series on public policy (Vol. 40, pp. 1-46). North-Holland.

Berensmann, K. (2004). New ways of achieving debt sustainability beyond the enhanced HIPC Initiative. Intereconomics, 39(6), 321-330.

Buchanan, M. (2005). Public principles of the public debt. Homewood: Illinois

Chenery, H. B., \& Carter, N. G. (1973). Foreign assistance and development performance, 1960 1970. The American Economic Review, 63(2), 459-468.

Claessens, S. (1990). The debt laffer curve: Some estimates. World Development, 18(12), 1671-1677.

Clements, B., Bhattacharya, R., \& Nguyen, T. (2003). External Debt, Public Investment, and Growth in Low-Income Countries. IMF Working Paper, IMF, Washington.

Cohen, D. (1993). Low Investment and Large LDC Debt in the 1980's. The American Economic Review, 437-449.

Easterly, W. (1993). How much do distortions affect growth?. Journal of Monetary economics, 32(2), 187-212.

Eaton, J. (1993). Sovereign debt: A primer. The World Bank Economic Review, 7(2), 137-172.

Feder, G. (1983). On exports and economic growth. Journal of development economics, 12(1-2), 5973.

Fekadu, M. (2014). The Impact of the External Debt on Economic Growth in Ethiopia. Master, Addis Ababa University.

Furceri, D., \& Zdzienicka, A. (2012). How costly are debt crises?. Journal of International Money and Finance, 31(4), 726-742.

Ghali, K. H. (1998). Public investment and private capital formation in a vector error-correction model of growth. Applied economics, 30(6), 837-844.

Hameed, A., Ashraf, H., \& Chaudhary, M. A. (2008). External debt and its impact on economic and business growth in Pakistan. International Research Journal of Finance and Economics, 20(1), 132-140.

Iyoha, M. A. (1999). External debt and economic growth in Sub-Saharan African countries: an econometric study. Research paper/African Economic Research Consortium; 90.

Jayaraman, T. K., \& Lau, E. (2009). Does external debt lead to economic growth in Pacific island countries. Journal of Policy Modeling, 31(2), 272-288. 
Johansen, S. (1988). Statistical analysis of cointegration vectors. Journal of economic dynamics and control, 12(2-3), 231-254.

Karagol, E. (2012). The causality analysis of external debt service and GNP: The case of Turkey. Central Bank Review, 2(1), 39-64.

Krugman, P. R. (1988). Financing vs. forgiving a debt overhang (No. w2486). National Bureau of Economic Research.

Likita (2000). External Debt Burden and the Capital Accumulation.

Maghyereh, A. I., \& Omet, G. (2002). External debt and economic growth in Jordan: The threshold effect. Available at SSRN 317541.

Melese Gizaw (2005). External debt and economic growth in Ethiopia. African institute for economic development and planning (IDEP), Dakar, Senegal.

Modigliani, F. (1961). Long-run implications of alternative fiscal policies and the burden of the national debt. The Economic Journal, 71(284), 730-755.

Mukui, G. K. (2013). Effect of external public debt on economic growth in Kenya (Doctoral dissertation, University of Nairobi).

Ng, S., \& Perron, P. (2001). Lag length selection and the construction of unit root tests with good size and power. Econometrica, 69(6), 1519-1554.

Pattillo, C. A., Poirson, H., \& Ricci, L. A. (2003). Through What Channels Does External Debt Affect Growth?. In Brookings Trade Forum (Vol. 2003, No. 1, pp. 229-258). Brookings Institution Press.

Pesaran, M. H., \& Shin, Y. (1998). An autoregressive distributed-lag modelling approach to cointegration analysis. Econometric Society Monographs, 31, 371-413.

Rahimi, M., \& Shahabadi, A. (2011). Trade liberalization and economic growth in Iranian economy. Available at SSRN 1976299.

Rockerbie, D. W. (1994). Did the debt crisis cause the investment crisis? Further evidence. Applied Economics, 26(7), 731-738.

Romer, D. (1996). Advanced Macroeconomics. The McGraw Hill, Inc.

Rose, A. K., \& Wincoop, E. V. (2005). National Money as a barrier to International trade.

Sachs, Jeffrey (1989). The Debt Overhang of Developing Countries," ed. by Calvo, A. Guillermo, and others, (Basil Blackwell: Oxford), p. 80-102.

Shuaib, I. M., \& Ndidi, N. D. E. (2015). Capital formation: impact on the economic development of Nigeria 1960-2013. European Journal of Business, Economics and Accountancy, 3(3), 23-40.

Siddique, M. A. B. (1996). The external debt problem of sub-Saharan Africa: 1971-1990. South African Journal of Economics, 64(2), 100-123.

Tadess, D. (2011). Source of economic growth in Ethiopia.

Teklu Tefera (2014). External Resource Mobilization and External Debt Situation”, Paper presented at a "Symposium for reviewing Ethiopia's Socio-Economic Performance 1991-1999". InterAfrican Group.

World Bank. (2017). World Development Indicators.

\section{Funding}

The authors received no direct funding for this research.

\section{Citation information}

Atinafu, W. (2020). External debt-growth nexus: Empirical evidence from Ethiopian economy. Economics, Management and Sustainability, 5(2), 6-27. doi:10.14254/jems.2020.5-2.1. 


\section{References}

Baba, I. (2013). Foreign direct investment inflows and economic growth in Ghana. International Journal of Economic Practices and Theories, 3(2).

Decai, T., \& K, B. (2012). China - Africa foreign trade policies: the impact of China's foreign direct investment (FDI) flow on employment of Ghana. 2012 International Conference on Future Energy, Environment, and Materials. 16, pp. 553-557. Energy Procedia.

Dr. John, A. (2005). What has been the impact of foreign direct investment in Ghana?. IEA Policy Analysis. The Institute of Economic Affairs, 1(9).

Francis, G., Mary, O., \& Jonatha, K. E. (2013). Foreign direct investment and gross domestic product in Ghana. International Journal of Academic Research in Accounting, Finance and Management Sciences, 3(3), 256-265.

George, O.-A., James, A., \& Peter, K. (2013). Foreign direct investment: A journey to economic growth in Ghana - Empirical Evidence. International Business \& Economics Research Journal, 12 (5).

IMF. (1993). Balance of Payments Manual, 5th edition. Washington D.C: International Monetary Fund.

Joseph, Y. A. (2015). Chinese Investment in Ghana. Argumenta Oeconomica Cracoviensia, (13), 61-81.

Justice, G., \& Gloria, C. (2012). Determinants and effects of foreign direct investment in Ghana Review of literature. Developing Country Studies, 2(11).

Kusi, G. (2013). Regulatory Framework for Investing in Ghana. Ghana Investment Promotion Centre.

Kwasi, B.-G., \& Yao, L. (2017). FDI trends in Ghana: The role of China, US, India and South Africa. Eurasian Journal of Economics and Finance, 5(2), 1-16.

OECD. (2008). OECD Benchmark definition of foreign direct investment. In OECD, OECD Benchmark Definition of Foreign Direct Investment (4th ed., pp. 62-64). Paris: OECD.

Prince, A., \& Victor, O. (2014). Foreign Direct Investment (FDI) Inflows into Ghana: Should the Focus Be on Infrastructure or Natural Resources? Short- Run and Long -Run Analyses. International Journal of Financial Research, 5(1).

Romer, P. (1986). Increasing returns and long run growth. Journal of Political Economy, 94(5), 10021037.

Samuel, K. F. (2012). Research on Relationship between China and Ghana: Trade and Foreign Direct Investment. Journal of Economics and Sustainable Development, 3(7).

Tee, E., Larbi, F., \& Johnson, R. (2017). The Effect of foreign direct investment (FDI) on the Ghanaian economic growth. Journal of Business and Economic Development, 2(5), 240-246.

Unctad. (2012). World investment report: Towards a new generation of investment policies. New York and Geneva: United Nations Conference on Trade and Development.

UNCTAD. (2008). World Investment Report: Transnational Corporations and the Infrastructure Challenge. New York: United Nations Conference on Trade and Development. 


\section{Appendixes}

\section{Appendix 1}

\begin{tabular}{|c|c|c|c|c|}
\hline \multicolumn{2}{|c|}{ Variables } & At level I(0) & $\begin{array}{c}\text { At } 1^{\text {st }} \text { difference } \\
\text { I (1) }\end{array}$ & $\begin{array}{c}\text { Order of } \\
\text { Integration }\end{array}$ \\
\hline \multirow[t]{2}{*}{ Ln Real GDP } & Intercept & 3.264 & $-4.643^{* *}$ & \\
\hline & Trend & 0.565 & $-5.633^{* *}$ & I (1) \\
\hline \multirow[t]{2}{*}{ Ln External Debt. } & Intercept & 0.783 & $-6.427^{* *}$ & \\
\hline & Trend & -1.534 & $-6.991^{* *}$ & I (1) \\
\hline \multirow[t]{2}{*}{ Ln Debt Servicing } & Intercept & -1.119 & $-6.001^{* *}$ & \\
\hline & Trend & -2.201 & $-4.210 * *$ & I (1) \\
\hline \multirow[t]{2}{*}{ Ln Trade Openness } & Intercept & -1.209 & $-5.448 * *$ & I (1) \\
\hline & Trend & -2.001 & $-5.406 * *$ & \\
\hline \multirow[t]{2}{*}{ Ln Physical capital } & Intercept & 1.821 & $-6.852^{* *}$ & \\
\hline & Trend & -0.570 & $-7.883^{* *}$ & I (1) \\
\hline \multirow[t]{2}{*}{ Ln Human capital } & Intercept & $-3.298^{* *}$ & $-4.026^{*}$ & \\
\hline & Trend & $-3.188^{* *}$ & $-4.067^{* *}$ & $\mathrm{I}(0)$ \\
\hline \multirow[t]{2}{*}{ Ln Labor force } & Intercept & -0.639 & $-5.939 * *$ & $\mathrm{I}(1)$ \\
\hline & Trend & 0.7162 & $-5.889 * *$ & \\
\hline
\end{tabular}

Note: * and ${ }^{* *}$ denote statistically significant at $1 \%$ and $5 \%$ levels respectively.

Source: author's computation using Stata 13

\section{Appendix 2}

\begin{tabular}{|c|c|c|c|c|}
\hline \multicolumn{2}{|c|}{ Variables } & At level I(0) & $\begin{array}{c}\text { At } 1^{\text {st }} \text { difference } \\
\text { I (1) }\end{array}$ & $\begin{array}{c}\text { Order of } \\
\text { Integration }\end{array}$ \\
\hline \multirow[t]{2}{*}{ Ln Real GDP } & Intercept & 1.662 & $-3.559^{* *}$ & \\
\hline & Trend & 0.484 & $-5.589 * *$ & $\mathrm{I}(1)$ \\
\hline \multirow[t]{2}{*}{ Ln External Debt } & Intercept & 1.789 & $-6.155^{* *}$ & \\
\hline & Trend & -1.426 & $-7.08^{* *}$ & $\mathrm{I}(1)$ \\
\hline \multirow[t]{2}{*}{ Ln Debt Servicing } & Intercept & 1.032 & $-4.963^{* *}$ & I (1) \\
\hline & Trend & -1.222 & $-5.124^{* *}$ & \\
\hline \multirow[t]{2}{*}{ Ln Trade Openness } & Intercept & -0.318 & $-5.568^{* *}$ & \\
\hline & Trend & -2.06 & $-5.272^{* *}$ & $\mathrm{I}(1)$ \\
\hline \multirow[t]{2}{*}{ Ln Physical capital } & Intercept & 1.028 & $-6.085^{* *}$ & \\
\hline & Trend & -0.392 & $-7.908^{* *}$ & $\mathrm{I}(1)$ \\
\hline \multirow[t]{2}{*}{ Ln Human capital } & Intercept & $-2.230 * *$ & $-3.270^{*}$ & \\
\hline & Trend & $-3.731^{* *}$ & $-4.089 *$ & $\mathrm{I}(0)$ \\
\hline \multirow[t]{2}{*}{ Ln Labor force } & Intercept & -1.208 & $-3.356^{* *}$ & $\mathrm{I}(1)$ \\
\hline & Trend & -1.487 & $-4.665^{* *}$ & \\
\hline
\end{tabular}

\section{Appendix 3}

\section{The critical values for bound test}

\begin{tabular}{lcccccc}
\hline \multicolumn{1}{c}{ Description } & \multicolumn{2}{c}{ At 10\% Level } & \multicolumn{2}{c}{ At 5\% Level } & \multicolumn{2}{c}{ At 1\% Level } \\
\cline { 2 - 6 } & $\begin{array}{c}\text { Lower } \\
\text { bound I(0) }\end{array}$ & $\begin{array}{c}\text { Upper } \\
\text { bound I(1) }\end{array}$ & $\begin{array}{c}\text { Lower } \\
\text { bound } \\
\mathrm{I}(0)\end{array}$ & $\begin{array}{c}\text { Upper } \\
\text { bound } \\
\mathrm{I}(1)\end{array}$ & $\begin{array}{c}\text { Lower } \\
\text { bound I(0) }\end{array}$ & $\begin{array}{c}\text { Upper } \\
\text { bound I(1) }\end{array}$ \\
\hline $\begin{array}{l}\text { Kripfganz and } \\
\begin{array}{l}\text { Schneider } \\
(2018) \quad \text { critical }\end{array}\end{array}$ \\
$\begin{array}{l}\text { values } \\
\mathrm{F}=8.095\end{array}$ & No. variables = 7 & 2.636 & 4.156 & 3.651 & 5.571 \\
\hline
\end{tabular}

Source: Pesaran, Shin, and Smith (2001) bounds test critical value 


\section{Appendix 4}

\section{Diagnostic tests result}

\begin{tabular}{|c|c|c|c|}
\hline Test statistics & Null - Hypothesis & LM version & F version \\
\hline Serial Correlation & No serial correlation & $\begin{array}{c}\operatorname{CHSQ}(1)= \\
1.2024[.234]^{* *}\end{array}$ & $\mathrm{~F}(3,39)=.62469[.423]^{* *}$ \\
\hline Functional Form & $\begin{array}{l}\text { No model is } \\
\text { correctly specified }\end{array}$ & $\begin{array}{c}\operatorname{CHSQ}(1)= \\
.011370[.716]^{* *}\end{array}$ & $\begin{array}{c}\mathrm{F}(3,38)= \\
.005331[.943]^{* *}\end{array}$ \\
\hline Normality & $\begin{array}{c}\text { Residuals are } \\
\text { normally distributed }\end{array}$ & $\begin{array}{c}\operatorname{CHSQ}(2)= \\
1.5745[.627]^{* *}\end{array}$ & Not applicable \\
\hline \multirow[t]{5}{*}{ Heteroscedasticity } & $\begin{array}{c}\text { No } \\
\text { heteroscedasticity }\end{array}$ & $\begin{array}{c}\text { CHSQ(1)= } \\
1.3321[.301]^{* *}\end{array}$ & $\mathrm{~F}(1,33)=1.3031[.263]^{* *}$ \\
\hline & \multicolumn{3}{|c|}{ A: Lagrange multiplier test of residual serial correlation } \\
\hline & \multicolumn{3}{|c|}{ B: Ramsey's RESET test using the square of the fitted values } \\
\hline & \multicolumn{3}{|c|}{ C: Based on a test of skewness and kurtosis of residuals } \\
\hline & \multicolumn{3}{|c|}{ D: Based on the regression of squared residuals on squared fitted values } \\
\hline
\end{tabular}

Note: The sign ** indicates the significance of each diagnostic tests $5 \%$ level of significance.

\section{Plot of Cumulative Sum of Recursive Residuals}

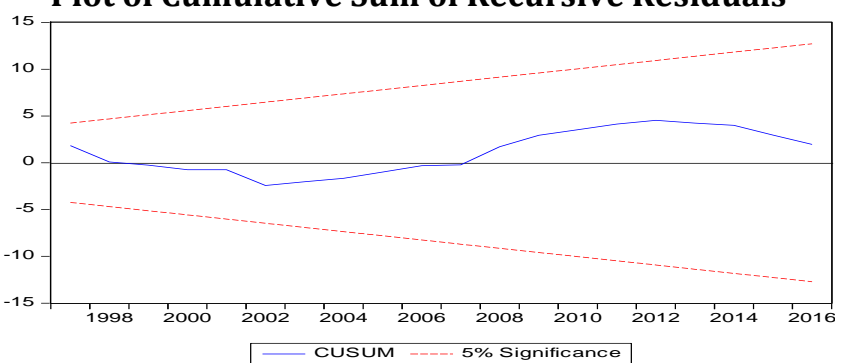

Plot of Cumulative Sum of Square of Recursive Residuals

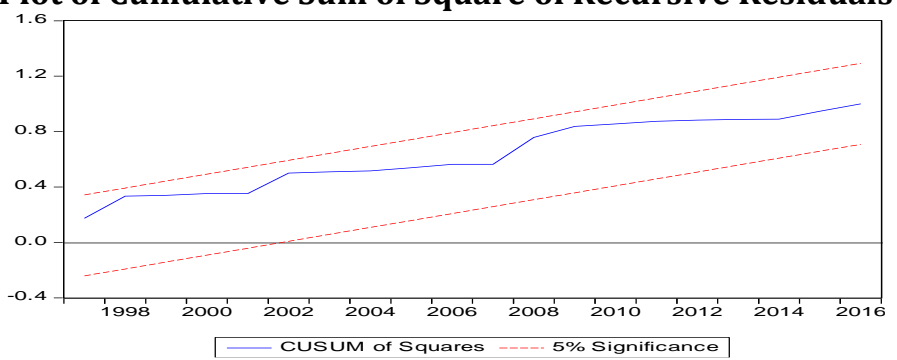

\section{Appendix 5: Bound test result}

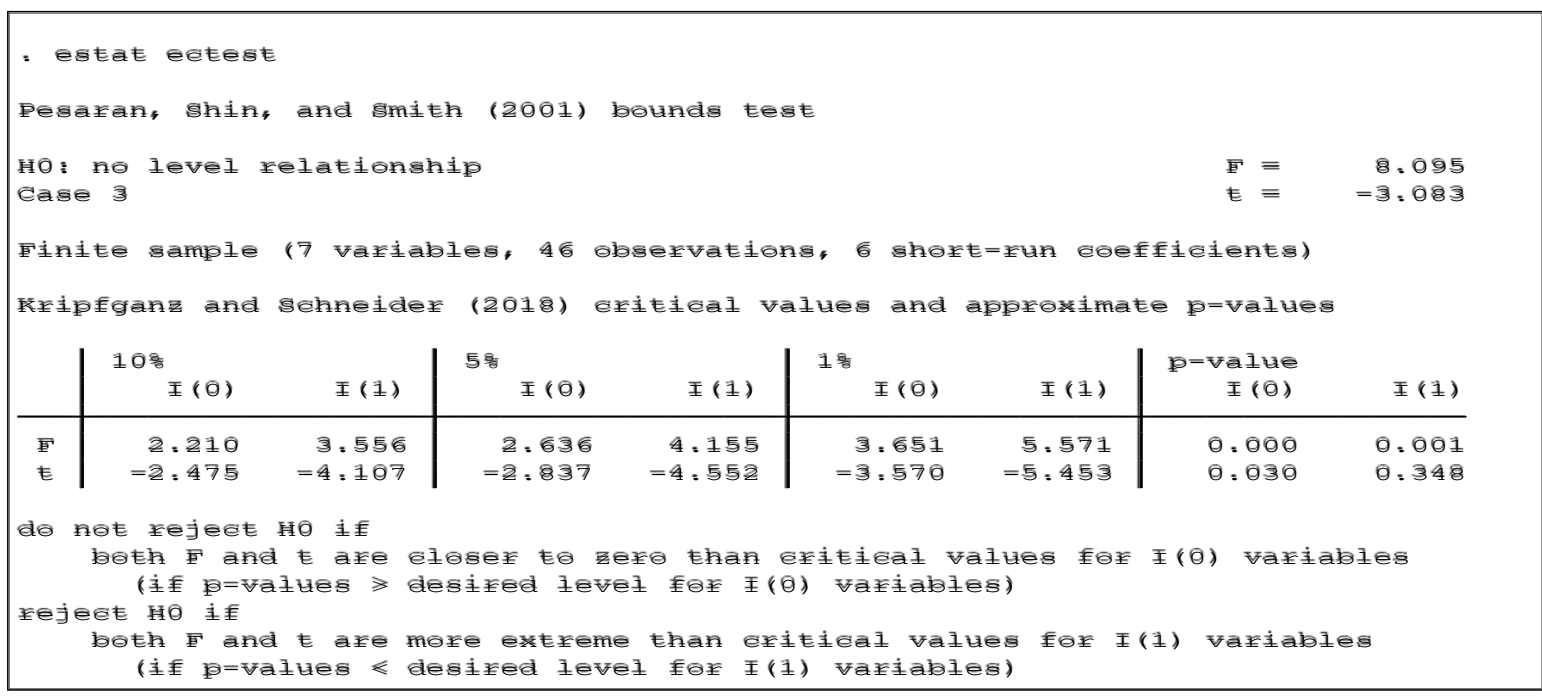




\section{Appendix 6: ARDL regression result (AIC lag selection criteria)}

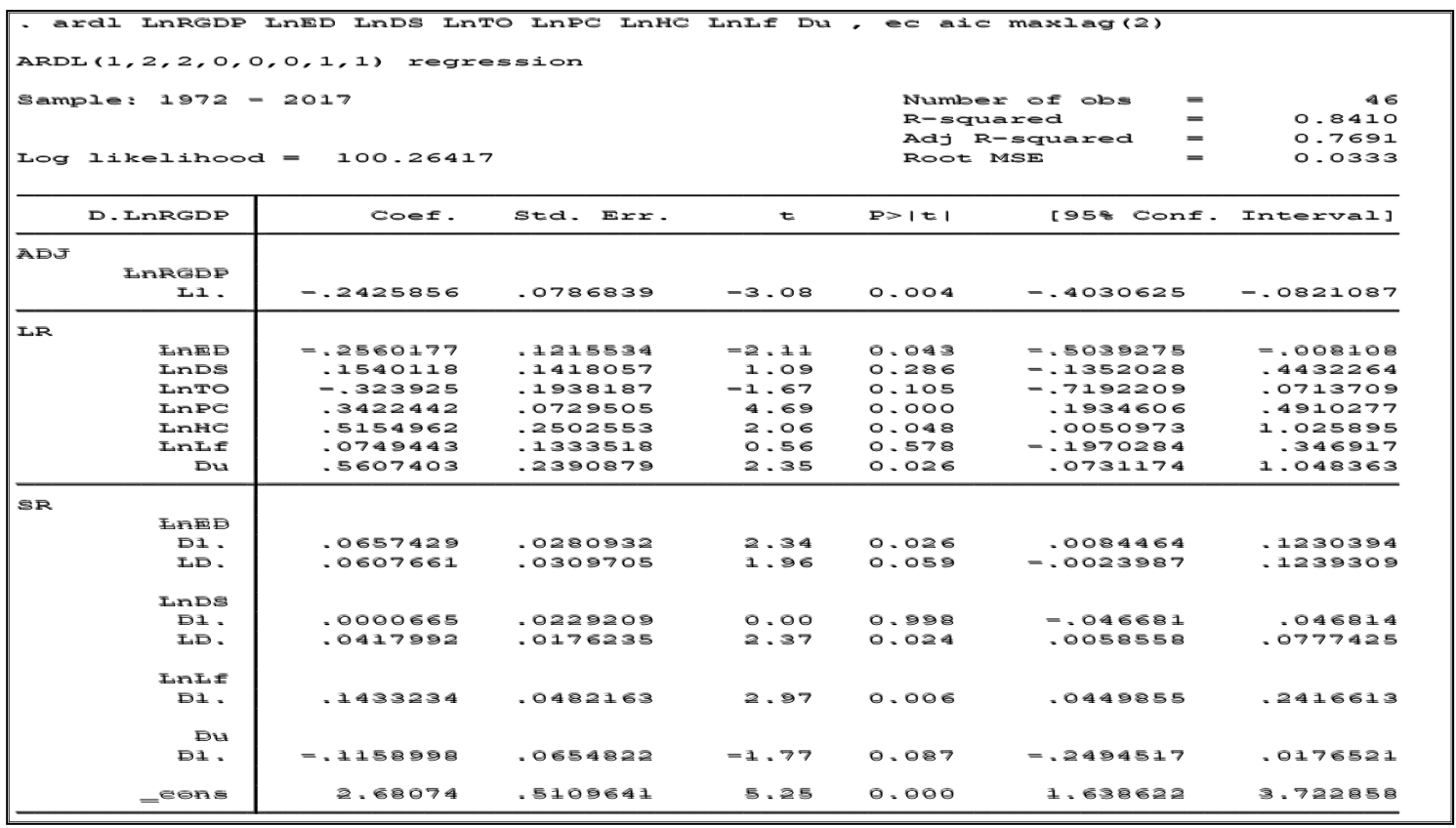

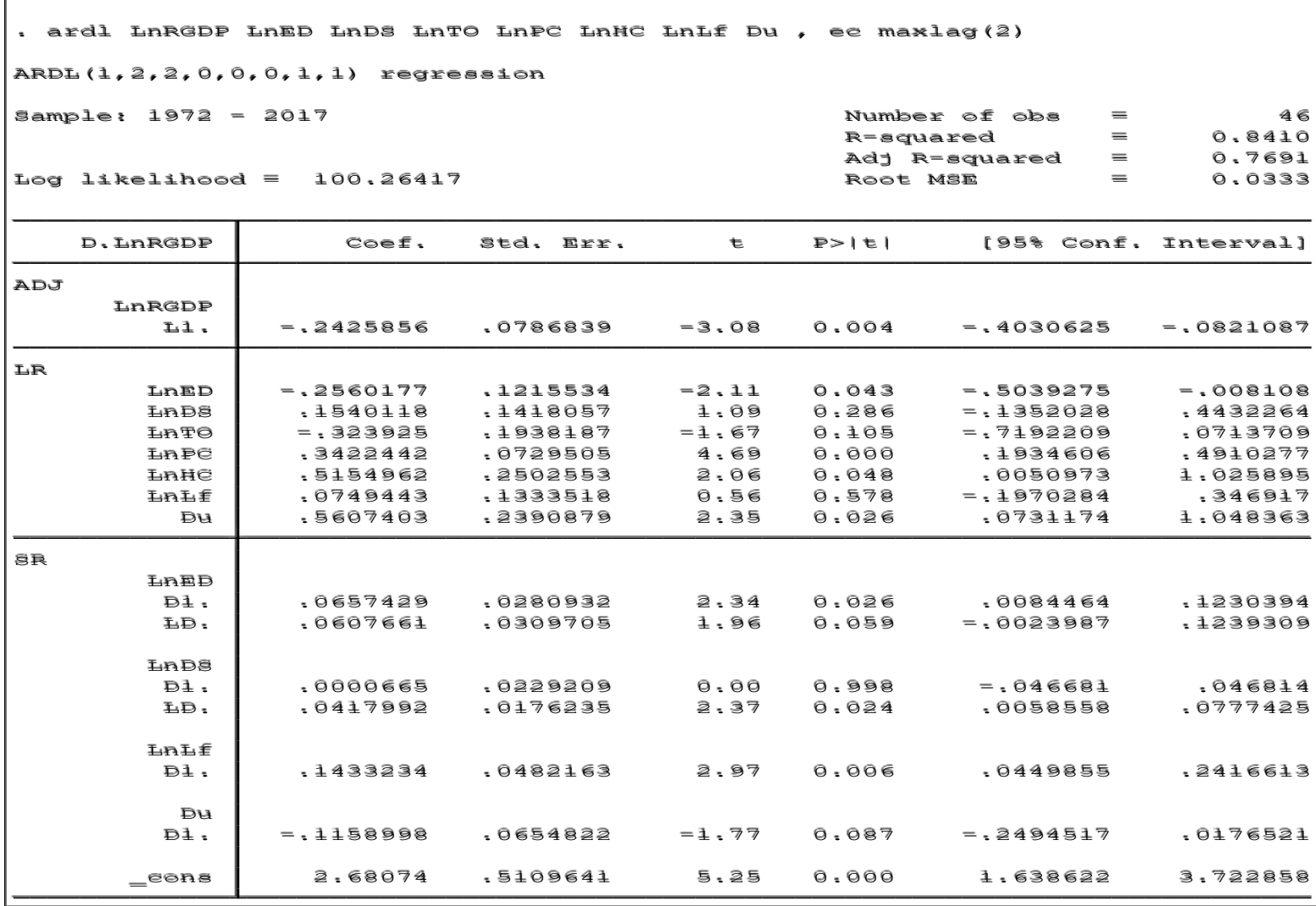




\section{Appendix 7: ARDL regression result (using SBIC lag selection criteria)}

Optimal lag length for each variable (AIC)

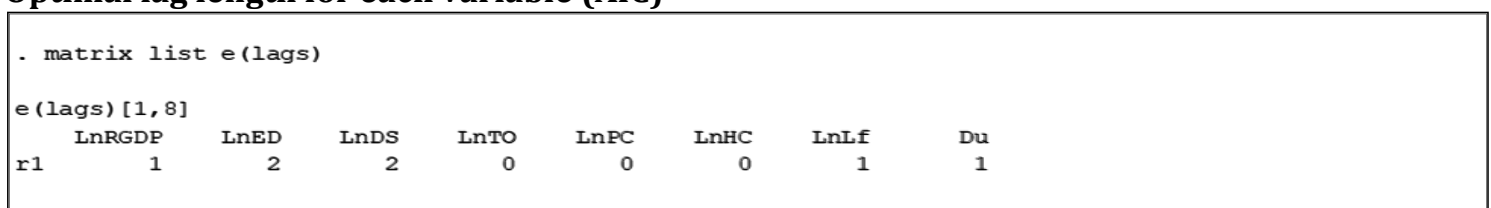

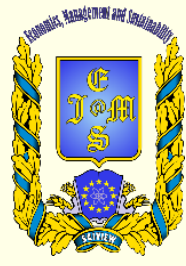

() 2016-2020, Economics, Management and Sustainability. All rights reserved.

This open access article is distributed under a Creative Commons Attribution (CC-BY) 4.0 license.

You are free to:

Share - copy and redistribute the material in any medium or format Adapt - remix, transform, and build upon the material for any purpose, even commercially.

The licensor cannot revoke these freedoms as long as you follow the license terms.

Under the following terms:

Attribution - You must give appropriate credit, provide a link to the license, and indicate if changes were made.

You may do so in any reasonable manner, but not in any way that suggests the licensor endorses you or your use.

No additional restrictions

You may not apply legal terms or technological measures that legally restrict others from doing anything the license permits.

Economics, Management and Sustainability (ISSN: 2520-6303) is published by Scientific Publishing House "CSR", Poland, EU and Scientific Publishing House "SciView", Poland

Poland, EU and Scientific Publis

Publishing with JEMS ensures:
- Immediate, universal access to your article on publication

- High visibility and discoverability via the JEMS website

- Rapid publication

- Guaranteed legacy preservation of your article

- Discounts and waivers for authors in developing regions

Submit your manuscript to a JEMS at http://jems.sciview.net or submit.jems@sciview.ne 